\title{
Результати хірургічного лікування об'ємних новоутворень наднирників
}

\author{
В. І. Пилипчук
}

Івано-Франківський національний медичний університет

\section{Results of surgical treatment of spacious tumors of suprarenal glands}

\author{
V. I. Pylypchuk \\ Ivano-Frankivsk National Medical University
}

\section{Реферат}

Мета. Вивчити результати лапароскопічної адреналектомії (ЛАЕ), виконаної з приводу об'ємних новоутворень наднирників (ОНН), з метою покращення діагностики та хірургічного лікування таких хворих.

Матеріали і методи. Проаналізовано результати ЛАЕ, виконаної 59 хворим у відділенні загальної хірургії ІваноФранківської обласної клінічної лікарні за період з 2013 по 2018 р. Чоловіків було 17 (28,8\%), жінок - 42 (71,2\%). Вік хворих коливався від 21 до 64 років, середній вік становив $(47,4 \pm 8,6)$ року. У 22 (37,7\%) хворих новоутворення локалізувались у правому наднирнику, у 37 (62,3\%) - у лівому. Для діагностики патологічних змін у наднирниках використовували лабораторні дослідження рівнів гормонів наднирників, ультразвукове дослідження (УЗД), комп’ютерну томографію (КТ), патогістологічне дослідження операційного матеріалу.

Результати. Синдром артеріальної гіпертензії мали 45 (76,3\%) хворих. Хірургічне лікування проведено за такими показаннями: синдром Кушинга, зумовлений доброякісною кортизол-продукуючою аденомою наднирника - 12 (20,3\%) хворих, хвороба Кушинга, лікування якої іншими методами не мало ефективності - 6 (10,2\%), синдром Конна - 12 (20,3\%), доброякісна феохромоцитома наднирника - 10 (16,9\%), нефункціональні аденоми наднирників та інші пухлини (діаметром 2 см і більше чи в разі постійного їх росту) - 19 (32,3\%). ЛАЕ виконували з трансабдомінального доступу. У ранньому післяопераційному періоді ускладнень не було. У віддалені строки після операції помірну артеріальну гіпертензію спостерігали у 5 (15,1\%) пацієнтів, наднирникову недостатність - у 1 (1,7\%) хворої.

Висновки. Комплексна діагностика ОНН з обов'язковим лабораторним дослідженням функції наднирників та використанням КТ дає змогу встановити чіткі показання до операції у кожного конкретного хворого. ЛАЕ є «золотим стандартом» хірургічного лікування хворих з ОНН, метод має добрі і задовільні результати у ранньому та віддаленому періоді. Доцільним є створення єдиного Національного реєстру пацієнтів з ОНН з постійним онлайн-оновленням, що дало б змогу більш детально та на великому клінічному матеріалі проаналізувати виконані оперативні втручання та їх результат.

Ключові слова: об’ємні новоутворення наднирників; адреналектомія; феохромоцитома; аденома наднирника; альдостерома.

\section{Abstract}

Objective. To study the results of laparoscopic adrenalectomy (LAE), performed for spacious tumors of suprarenal glands (STSG), for improvement of diagnosis and surgical treatment of patients.

Materials and methods. Results of LAE, performed in 59 patients in Department of General Surgery of Ivano-Frankivsk Regional Clinical Hospital in 2013 - 2018 yrs were analyzed. There were 17 (28.8\%) men and 42 (71.2\%) women. The patients were $21-64$ yrs old, and the average age have constituted (47.4 \pm 8.6$)$ yrs. In $22(37.7 \%)$ patients the tumors were localized in right suprarenal gland, and in 37 (62.3\%) - in a left one. Laboratory investigations of the suprarenal glands hormones levels, ultrasonographic investigations, computer tomography (CT), pathohistological investigation of operative material were used for diagnosis of pathological changes in suprarenal glands.

Results. Syndrome of arterial hypertension have had 45 (76.3\%) patients. Surgical treatment was conducted in accordance to following indications: Cushing syndrome, caused by benign cortisol-producing adenoma of suprarenal gland, - 12 (20.3\%) patients, Cushing disease, treatment of which using other methods was noneffective, -6 (10.2\%), Conn's syndrome -12 (20.3\%), benign pheochromocytoma of a suprarenal gland - 10 (16.9\%), nonfunctional adenomas of suprarenal glands and other tumors ( $2 \mathrm{~cm}$ and more in diameter or in a case of their constant growth) - 19 (32.3\%). LAE was performed from transabdominal access. In early postoperative period the morbidity was absent. In remote postoperative period a moderate arterial hypertension was observed in 5 (15.1\%) patients, and insufficiency of suprarenal glands - in 1 (1.7\%).

Conclusion. Complex diagnosis of STSG with obligatory laboratory investigation of the suprarenal glands function and application of CT permits to establish strict indications for the operation in every individual patient. LAE constitutes a "gold standard» of surgical treatment of patients, suffering STSG, the method owes good or satisfactory results in early and remote period. It is expedient to create the only one National Registry of patients, suffering STSG with constant online-renovation, what would give possibility for more detailed and on large clinical material analyzing of the operative interventions performed and their result.

Keywords: spacious tumors of suprarenal glands; adrenalectomy; pheochromocytoma; adenoma of suprarenal gland; aldosteroma. 
Об'ємні новоутворення наднирників (ОНН) діагностують не досить часто, оскільки вони не мають специфічних клінічних симптомів. За останні роки кількість таких хворих зросла, що пов'язано з покращенням діагностики, широким застосуванням у клінічній практиці КТ, магнітно-резонансної томографії (МРТ), більшою інформованістю та настороженістю лікарів -терапевтів, кардіологів, ендокринологів. У даний час частота ОНН становить 3 - 9 спостережень на 100 тис. населення [1].

Рівень ранньої діагностики пухлинних утворень наднирників недостатній, доопераційна диференціальна діагностика їх доброякісних та злоякісних новоутворень недосконала [2].

Через неспецифічність клінічних проявів захворювань наднирників пацієнтів часто лікують різні спеціалісти, зокрема, хворих з гормонально-активними пухлинами мозкового шару (феохромоцитомами) та пухлинами коркового шару з гіперпродукцією альдостерону (альдостеромами) - терапевти та кардіологи з приводу артеріальної гіпертензіі, хворих з гормонально-активними пухлинами коркового шару (синдромом Іценко-Кушинга, вірільним синдромом) - ендокринологи.

На сучасному етапі ЛАЕ вважають «золотим стандартом» лікування доброякісних гормонально-активних та невеликих доброякісних гормонально-неактивних пухлин наднирників [3, 4]. Мініінвазивні оперативні втручання сприяють зменшенню частоти інтра- та післяопераційних ускладнень, покращенню якості життя пацієнтів [4, 5].

Мета дослідження: вивчити результати ЛАЕ, виконаних з приводу ОНН з метою покращення діагностики та хірургічного лікування таких хворих.

\section{Матеріали і методи дослідження}

За період з 2013 по 2018 р. у відділенні загальної хірургії Івано-Франківської обласної клінічної лікарні хірургічне лікування проведено 59 хворим з ОНН. Чоловіків було 17 (28,8\%), жінок - 42 (71,2\%). Вік хворих коливався від 21 до 64 років, середній вік становив $(47,4 \pm 8,6)$ року. Проте пацієнтів віком 41 - 50 років було найбільше - 34 (57,6\%). У 22 (37,7\%) хворих новоутворення локалізувались у правому наднирнику, у 37 (62,3\%) - у лівому.

Для діагностики патологічних змін у наднирниках використовували лабораторні дослідження гормонів коркового та мозкового шарів наднирників, УЗД, КТ, патогістологічне дослідження операційного матеріалу. Хворих обов'язково консультували ендокринолог та кардіолог. Доопераційну біопсію ОНН не застосовували через ії малу інформативність. Для оцінки віддалених результатів оперативного лікування хворих оглядали, проводили УЗД, КТ та визначали рівні гормонів.

\section{Результати}

Клінічні прояви захворювань наднирників були неспецифічними, тривали від 6 міс до 5 років, у середньому $(3,2 \pm 0,4)$ року.

Синдром артеріальної гіпертензії мали 45 (76,3\%) хворих. У 32 (71,1\%) з них проявами гіпертензіі були гіпертонічні кризи, у 13 (20,9\%) - персистуючі стрибки тиску. Безсимптомним перебіг захворювання був у 14 (23,7\%) хворих, у них ОНН ви- явлено випадково під час проведення УЗД чи КТ з приводу інших захворювань. Після додаткового дослідження гормонального фону встановили, що пухлини гормонально-неактивні, відхилень від нормальних рівнів катехоламінів та їх похідних у сироватці крові та сечі не виявили.

У більшості хворих з гормонально-активними пухлинами наднирників екскреція адреналіну була підвищена в середньому в 2,5 разу, норадреналіну - у 2 рази, альдостерону - у 2 рази і більше.

У 9 (15,2 \%) хворих був цукровий діабет.

За даними УЗД розміри ОНН коливались від $65 \times 86$ до $17 \times 20$ мм, у середньому у $(45,6 \pm 6,4) \times(56,4 \pm 8,0)$ мм, КТ - від 20 до 86 мм, у середньому (59,6 24 24,3) мм. Гормонально-неактивні ОНН мали розміри від 17 до 68 мм, у середньому $(48,6 \pm 22,2)$ мм, гормонально-активні - від 19 до 86 мм, у середньому $(65,4 \pm 26,1)$ мм.

Вибираючи показання до оперативного лікування, керувались результатами досліджень R. V. Barresi i R. A. Prinz [6] та М. Ю. Ничитайла і співавторів [3]. Хірургічне лікування з приводу синдрому Кушинга, зумовленого доброякісною кортизол-продукуючою аденомою наднирника, проведено 12 (20,3\%) хворим; хвороби Кушинга, інші методи лікування якої були неуспішні - 6 (10,2\%); синдрому Конна (альдостерон-продукуючої аденоми наднирника) - 12 (20,3\%); доброякісної феохромоцитоми наднирника - 10 (16,9\%); нефункціональних аденом наднирників та інших пухлин (діаметром 2 см і більше чи в разі постійного їх росту) - 19 (32,3\%).

До опанування лапароскопічним методом у 2007 - 2010 рр. адреналектомію виконували з лапаротомного доступу. 32010 р. в хірургічну практику впровадили та широко використовуємо ЛАЕ.

Передопераційна підготовка хворих була спрямована на нормалізацію артеріального тиску (АТ), корекцію вуглеводного обміну (у хворих з цукровим діабетом). Хворі із субклінічним перебігом захворювання та без супутніх захворювань особливої передопераційної підготовки не отримували. Пацієнтів повністю обстежували та проводили їм максимальну передопераційну підготовку амбулаторно або в умовах ендокринологічного стаціонару. Тому оперативне втручання виконували в день планової госпіталізації пацієнта чи наступного дня.

Під час виконання лапароскопічних втручань перевагу надавали трансабдомінальному доступу, якому властиві більша робоча порожнина, краща орієнтація абдомінального хірурга, добрий косметичний ефект. ОНН розмірами більше 5 - 6 см не були протипоказанням до застосування лапароскопічного методу операції.

Операцію виконували в латеропозиції хворого під кутом $45^{\circ}$. Виконуючи ЛАЕ справа, використовували чотири порти. Перший порт (10 мм) встановлювали в біляпупковій ділянці. Після огляду черевної порожнини під контролем зору встановлювали 2 порти (5 мм) для робочих інструментів по середньоключичній та середньоаксілярній лініях у правій підреберній ділянці та один порт (10 мм) в епігастральній ділянці. Далі мобілізували товсту та дванадцятипалу кишки, виконували тракцію печінки доверху та ідентифікували нижню порожнисту вену. Після верифікації наднирника спочатку мобілізували та кліпували 
його судини. Перед кліпуванням особливу увагу надавали верифікації нижньої порожнистої вени, куди впадає вена наднирника. Далі виділяли наднирник та частково паранефральну клітковину.

Виконуючи ЛАЕ зліва, використовували також чотири порти, розміщення яких було практично дзеркально протилежним. Мобілізували селезінковий кут товстої кишки та селезінку. Після розсічення фасції Герота візуалізували верхній полюс нирки, виділяли вену наднирника, яку кліпували та пересікали. До кліпування вени наднирника обов'язково чітко ідентифікували ниркову вену. Наднирник видаляли. Особливу увагу приділяли ідентифікації хвоста підшлункової залози для уникнення його травматизації та профілактики післяопераційного панкреатиту. Всі оперативні втручання завершували обов'язковим дренуванням ложа видаленого наднирника.

У 2 (3,4\%) хворих з ОНН лівого наднирника в період опанування лапароскопічною методикою операції виникли технічні труднощі в мобілізації наднирника через кровотечу, здійснено конверсію та втручання завершено з лапаротомного доступу. У решти 57 (96,6\%) хворих операцію виконано повністю лапароскопічно. Проте у 5 хворих з лівобічним розміщенням новоутворень під час операції виникла кровотеча різної інтенсивності з ложа наднирника, що утруднило продовження втручання. Кровотечу зупинили та закінчили операції лапароскопічно. Останні два роки завдяки застосуванню сучасної електрохірургічної техніки, зокрема біполярної та аргоновоплазмової коагуляції, ризик інтраопераційної кровотечі вдалось звести практично до мінімуму.

Під час операції у 37 (62,7\%) хворих виникло коливання АТ на етапі виділення пухлини з наступним його зниженням після кліпування вени наднирника. Інтраопераційні коливання АТ були максимальними у хворих з вираженою симптоматикою феохромоцитоми та доопераційним підвищенням рівня катехоламінів у лабораторних тестах. У хворих з гормонально-неактивними ОНН значущих змін гемодинаміки під час операції не було.

Тривалість ЛАЕ коливалась від 48 до 135 хв і становила у середньому $(85 \pm 15)$ хв. Інтраопераційна крововтрата становила 30 - 120 мл, у середньому (80 \pm 15$)$ мл, тому потреби в гемотрансфузії не було.

У ранньому післяопераційному періоді 7 (11,8\%) хворих скаржились на біль в епігастральній ділянці, не пов'язаний з прийомом їжі. Оскільки у всіх хворих в алгоритм доопераційного обстеження входило проведення ендоскопічного дослідження шлунка та дванадцятипалої кишки і патологічних змін у них виявлено не було, больовий синдром розцінили як функціональний. Пацієнтам призначили обволікаючі препарати на 2 - 3 дні, біль зник.

Iз 45 хворих з доопераційною артеріальною гіпертензією нормалізацію АТ у ранні строки після операції спостерігали у 24 (53,3\%). У 19 (42,2\%) хворих після операції відзначено значне зменшення гіпертензії, проте АТ під час перебування у стаціонарі не нормалізувався. Цим пацієнтам лікар-кардіолог скоригував дози гіпотензивних препаратів. Ще у 2 хворих після адреналектомії з приводу гормонально-активних новоутворень виникла гіпотензія як прояв наднирникової недостатності. Проте вона була скоригована введенням симпатоміметиків та кортикостероїдів протягом 2 - 3 днів. У хворих з гормональнонеактивними ОНН змін гемодинаміки не спостерігали.

Повторних оперативних втручань у хворих не виконували, після ЛАЕ не помер жоден хворий.

Для післяопераційного знеболювання використовували одноразово наркотичні аналгетики в день операції, далі - ненаркотичні аналгетики та нестероїдні протизапальні препарати.

Тривалість перебування хворих у стаціонарі становила $(4,6 \pm 0,4)$ дня, після операції - $(3,5 \pm 0,6)$ дня.

Отримано такі патогістологічні висновки: доброякісні аденоми - у 18 (30,6\%) хворих; кістозні доброякісні новоутворення - у 6 (10,1\%); кортикостерома - у 12 (20,3\%) хворих; адренокортикальний рак - у 1 (1,8\%).

Віддалені результати оперативних втручань в строки від 6 міс до 5 років простежені у 33 (55,9\%) хворих. У 5 $(15,1 \%)$ пацієнтів спостерігали помірну артеріальну гіпертензію, вони періодично приймали гіпотензивні препарати. У 1 хворої з феохромоцитомою після ЛАЕ виникла необхідність у замісній терапії з приводу наднирникової недостатності. Всі інші пацієнти скарг, пов'язаних з оперативним втручанням, не мали.

\section{Обговорення}

На даний час методом вибору хірургічного лікування ОНН вважають ЛАЕ. У зв'язку з відносно невеликою поширеністю ОНН ще не накопичено достатній дослідницький матеріал, який дав би змогу сформулювати чіткі показання до операції, розробити критерії оцінки ранніх та віддалених результатів. Недостатньо вивчено доцільність та правомірність виконання мініінвазивних втручань 3 приводу ОНН великих розмірів та злоякісних новоутворень, особливо, коли необхідно виконувати лімфодисекцію.

Потребує подальшого вивчення виконання ЛАЕ у хворих з клінічними проявами артеріальної гіпертензії, що погано піддається корекції, за нормальних лабораторних показників рівнів гормонів наднирників та наявності ОНН невеликих розмірів (до 1 см). Ми маємо позитивний досвід виконання втручань у 3 таких хворих. Після ЛАЕ у них нормалізувався АТ.

Перспективою подальших досліджень було б створення Національного реєстру пацієнтів з ОНН із занесенням даних про виконане їм оперативне втручання, ранні та віддалені результати операції онлайн в єдину базу.

\section{Висновки}

1. Комплексна діагностика ОНН з обов'язковим лабораторним дослідженням функції наднирників та використанням КТ дає змогу встановити чіткі показання до операції у кожного конкретного хворого.

2. ЛАЕ $є$ «золотим стандартом» у хірургічному лікуванні хворих з ОНН та має добрі і задовільні ранні та віддалені результати.

3. Доцільно створити єдиний Національний реєстр пацієнтів з ОНН з постійним онлайн-оновленням, що дало б змогу більш детально та на великому клінічному матеріалі проаналізувати виконані оперативні втручання та їх результат. 


\section{References}

1. Kashtalian MA, Shapovalov VIu, Tymchuk OB, Herasymenko OS. Vydeolaparoskopyia v lechenyy novoobrazovanyi nadpochechnykov. Shpytalna khirurhiia. 2015;(1):94-6. [In Russian].

2. Zografos GN, Farfaras A, Vasiliadis G, Pappa T, Aggeli C, Vasilatou E, et al. Laparoscopic Resection of Large Adrenal Tumors. JSLS. 2010 Jul-Sep; 14(3): 364-368. doi: 10.4293/108680810X12924466007160.

3. Nichitaylo ME, Litvinenko A. N., Guhlko ON, Kvachenyuk AN, Lukecha I. I. Laparoscopic adrenalectomy in surgery of the adrenal gland diseases. Klinichna khirurhiia. 2013;(2):20-4. [In Russian].
4. Hulyev BH, Semenov DV. Laparoskopycheskaya transperytonealnaya adrenalektomiya: nash opyt. Onkourolohiya. 2014;(4):75-5. [In Russian].

5. Sadryev ON, Haybov AD. Obosnovaniye vybora khirurhycheskoho dostupa dyia adrenalektomii. Novosty khyrurhyy. 2015 Mar-Apr;23(2):14553. [In Russian].

6. Barresi RV, Prinz RA. Laparoscopic adrenalectomy. Arch Surg. 1999 Feb;134(2):212-7. PMID: 10025466. 